This item was submitted to Loughborough's Research Repository by the author.

Items in Figshare are protected by copyright, with all rights reserved, unless otherwise indicated.

\title{
Wind resource potential in Los Taques-Venezuela
}

PLEASE CITE THE PUBLISHED VERSION

http://dx.doi.org/10.1109/TLA.2015.7111999

\section{PUBLISHER}

(c) IEEE

VERSION

AM (Accepted Manuscript)

\section{PUBLISHER STATEMENT}

This work is made available according to the conditions of the Creative Commons Attribution-NonCommercialNoDerivatives 4.0 International (CC BY-NC-ND 4.0) licence. Full details of this licence are available at: https://creativecommons.org/licenses/by-nc-nd/4.0/

\section{LICENCE}

CC BY-NC-ND 4.0

\section{REPOSITORY RECORD}

Gonzalez-Longatt, Francisco M.. 2019. "Wind Resource Potential in Los Taques-venezuela”. figshare. https://hdl.handle.net/2134/17704. 


\title{
Wind Resource Potential in Los Taques- Venezuela
}

\author{
F. Gonzalez-Longatt, IEEE Senior Member
}

\begin{abstract}
The Venezuelan government has established more aggressive policies and incentives for renewable energy resources in recent time, especially in terms of wind power. Although several academic efforts to make publically available wind energy resource data in Venezuela, there is a lack of information in terms of local wind resource putting in risk development in areas where potential is good enough for commercial exploitation. The objective of this paper is to presents a very comprehensive wind resource assessment at Los Taques, Venezuela based on on-site observation anemometry. This is unique paper because it is the first ever wind energy assessment in Los Taques using hourly data recorded during three years in an on-site ground weather station contrary to studies based on daily values based on radar or satellite data. The applied methodology has been developed based on the characteristic of the data obtained from the on-site anemometry. Results of wind energy assessment and evaluations on a $100 \mathrm{MW}$ wind farm shows the wind energy resource available in Los Taques is enough for commercial use and the results.
\end{abstract}

Keywords - Wind data, Wind Energy potential, Wind power generation, Venezuela.

\section{INTRODUCTION}

$\mathrm{T}$ HE Bolivarian Republic of Venezuela is a country which has the largest electricity consumption in South America $(4,018 \mathrm{KWh} /$ year per capita) and electrical power system provide electricity to $95 \%$ Venezuelan population [1]. The demand peak value varies between 16,500 MW and 18,200 MW depending on seasonal conditions [2], [3]. Electricity consumption rises between $4 \%$ and $7 \%$ per year, and it is expected to increase with the same or higher rate in the next 10 years [2]. Total generation installed capacity is $26,550 \mathrm{MW}$ and the generation mix is $65 \%$ hydropower, $32 \%$ thermal power plants and $3 \%$ distributed energy resources [1]. Although the proven oil reserves in Venezuela are claimed to be one of the largest in the world, more aggressive policies on the use of environmentally friendly electricity generation have begun in recent years in Venezuela.

Several academic projects have been reported to promote renewable energy sources installations in numerous areas of Venezuela [4], [5], [6] especially wind power. Several smallscale and off-grid wind power projects have been developed and two utility-scale wind have been installed in mainland Venezuela: La Guajira (25 MW) [7], and La Peninsula de Paraguaná (100 MW) [8].

A wind atlas of Venezuela has been recently published by the author in [1] where several areas have been identified suitable for wind energy projects, including the Paraguaná area

F. Gonzalez-Longatt is with the School of Electronic, Electrical and Systems Engineering Centre for Renewable Energy Systems Technology (CREST), Loughborough University. Loughborough, LE11 3TU, United where the Paraguaná Wind Farm is installed [8]. However, there is not information, publically available to allow enforce more development of wind energy use in the area of Santa Cruz de los Taques (or Los Taques as known).This paper is a first effort make publically available information about the wind resource potential available at Los Taques-Venezuela, it will allow to local population a valuable insight into the wind resource, its potential development, and its value to a utility utilization of individual use.

The objective of this paper is to presents a very comprehensive wind resource assessment at Los Taques, Venezuela based on on-site observation anemometry. Section II describes briefly the analysis method for the assessment in the study area whilst Section III to $\mathrm{V}$ present the results gathered and a discussion of their significance. Data used in this paper is based on the available wind data measurement from on-site observation anemometry. From the results of this paper, Los Taques is identified as suitable site for the wind energy exploitation in Venezuela. Conclusions of this paper suggest further site-specific investigations should be conducted evaluating economical of potential wind energy development.

\section{Methodology Wind Potential Assessment}

Wind energy site assessment evaluates the potential for a given site to produce energy from wind turbines. There are several approaches to investigate the wind resource within a given area of land [9] and the preferred approach is defined by objectives of the wind energy program. [10]. However, there is a general consensus as to how wind energy site assessment is performed. The Wind Resource Assessment Handbook [11], Wind Energy - The Facts (Volume 1, Chapter 2) [12], consulting firms [13], and state guidebooks on site assessment [14], all endorse a similar site assessment methodology. As summarized in [15], there are a number of methods for estimating the wind resource of an area [16], [17]. A detailed review of all of these methods is beyond the scope of this paper. Aspects of wind resource evaluation based on measurement only are presented in this paper. This approach has been applied successfully in several locations around the world [18-23].

Fig. 1 shows a complete flow chart of the methodology for the wind resource assessment followed in this paper. This methodology has been developed by the author based on the characteristic of the data obtained from the on-site anemometry. This simplify procedure follows a sequence of three steps: (1) data validation, (2) data recovery, and (3) data processing.

Kingdom. He is Vice-President of Venezuelan Wind Energy Association fglongatt@fglongatt.org. 
The main input data for the site wind resource assessment procedure is on-site measurement data, time series, relating to different meteorological parameters: wind speed, wind direction, air temperature, and atmospheric air pressure.

The onsite measured data must be validated and processed in order to generate adequate information to allow wind resource assessment. The data validation process consists of the inspection of all the collected data for both completeness and integrity as well as the elimination of any erroneous values. There is several validation routines designed to screen each measured parameter for suspect values before they are incorporated into the archived database and used for site analysis. Manually and automatically routines are used for validation purposes in this paper. Details of validation tests are presented in next section.

When the data validation step is complete, the data set must be subjected to various data processing procedures to assess the wind resource [24], [25]. This typically involves performing calculations on the data set, as well as binning (sorting) the data values into useful subsets based on your choice of averaging interval. The processed data can be analysed in many different ways. However, there is a general consensus about the use of descriptive statistic in preliminary assessment and resource description to quantitatively describing the main features of wind resource. In the following subsections, the treatments used for the processing of valid data used in this paper are presented.

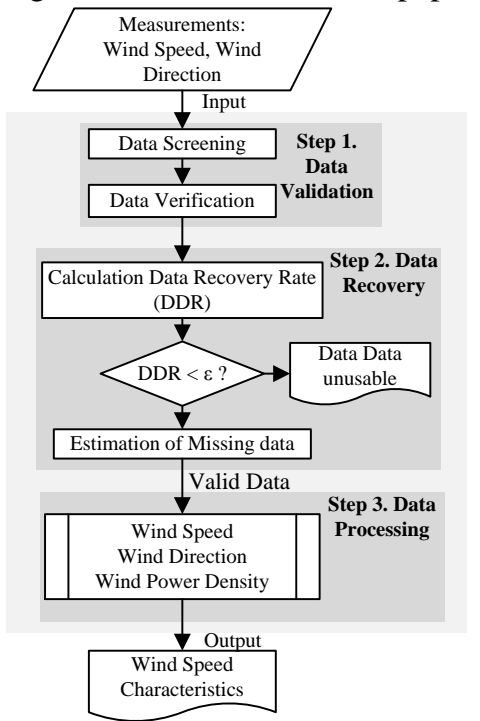

Fig. 1. Flow Chart of Methodology for Processing of Wind Data Set and Wind Resource Assessment.

\section{A. Descriptive Statistic Wind Energy}

The procedure of determining if a site is suitable for wind power production requires convincing statistical information describing the long-term behaviour of the wind resource. Several statistical indicator of wind energy resource are used in the specialized literature. Average speed indicates the overall wind potential at a given site, expected wind speed for a given time interval (first central moment). The variability of wind speed in a given time-series is calculated by the standard deviation $\left(\sigma_{m}\right)$. It indicates the mean amplitude of temporal (or spatial) wind fluctuations (square root of the variance).

Probability density functions (PDF) such as the Weibull or
Rayleigh functions are usually used to determine the wind speed distribution of a windy site for a period of time. Wind speed distributions are used as stochastic representation of the wind resource at the studied site, Weibull probability density function is used in this paper and the maximum likelihood method is used to obtain distribution parameters [9],[26].

\section{B. Energy Output and Wind Power Density (WPD)}

The process to estimate the energy output of a wind turbine in the measured wind regime consists of four main steps. First, it estimates the wind speed at the hub height of the wind turbine for each time record in the data set (time step). Second, it uses the hub height wind speed and air density for each time step to estimate the gross power output of the wind turbine for each time [9]. Third, it finds the overall mean and the mean for each month of the gross power output, and multiplies this value by the overall loss factor to calculate the mean net power output, for each month and for the entire data set. Finally, it multiplies the mean net power output by the number of hours in a year (8760) to find the net annual mean energy production. Similarly, it multiplies the monthly mean net power outputs by the number of hours in each month to find the net monthly mean energy production. Full details of this methodology are found several publications [9], [16].

Apart from wind speed, the kinetic energy content of the atmosphere also depends linearly on air density [27]. Nearsurface air density is defined as the mass of a quantity of air divided by its volume. It can be calculated using the ideal gas law.

\section{DATA SOURCE}

The data used in this paper was obtained from the meteorological station of the Josefa Camejo Airport (IATA: LSP), located at coordinates of $11^{\circ} 46^{\prime} 07^{\prime \prime} \mathrm{N}$ and $70^{\circ} 08^{\prime} 09^{\prime \prime} \mathrm{W}$ at $23 \mathrm{~m}$ above sea level. This site is found to be the most suitable information source in the area for developing the preliminary wind energy assessment of Los Taques as there are no obstacles around the measurement area so it is directly open to the Venezuelan Gulf to the west. The collected data covers three years period, from $1^{\text {st }}$ January 2008 to $31^{\text {st }}$ December 2010 (1096 days). This station recorded the wind speed, wind direction, temperature, humidity and atmospheric pressure on an hourly basis. The terrain in the surrounding area is relatively flat and suitable for wind power development with very low surface roughness conditions. A three cup anemometer and a wind vane are mounted individually on cross arm supported by single tubular pole, which was erected in July 2007.

TABLE I. NOMINAL CHARACTERISTICS AND SPECIFICATIONS OF THE MEASURING EQUIPMENT AT ON-SITE WEATHER STATION.

\begin{tabular}{cccc}
\hline \hline & $\begin{array}{c}\text { Measurement } \\
\text { range }\end{array}$ & Accuracy & Resolution \\
\hline Anemometer & $0-160 \mathrm{mph}$ & $\pm 0.15 \mathrm{mph}$ & $0.05 \mathrm{mph}$ \\
& $0-71 \mathrm{~m} / \mathrm{s}$ & or $1 \%$ & $<1.0^{\circ}$ \\
Wind vane & $0-360^{\circ}$ & $\pm 2 \%$ & $0.05{ }^{\circ} \mathrm{C}$ \\
Thermometer & $(-40)-(+60)^{\circ} \mathrm{C}$ & $\pm 0.1^{\circ} \mathrm{C}$ & $0.05 \%$ \\
Hygrometer & $0-100 \% \mathrm{RH}$ & $\pm 1.5 \% \mathrm{RH}$ & $0.01 \mathrm{hPa}$ \\
Barometer & $500-1100 \mathrm{hPa}$ & $\pm 0.05 \mathrm{hPa}$ &
\end{tabular}

Temperature, relative humidity and atmospheric pressure data are obtained from a thermometer, a hygrometer and a 
barometer, respectively. A data logger is connected to the sensors on the mast to collect data in time series. Table I shows the technical specification of the main measurement devices installed at the weather station and all wind sensors are mounted according to the World Meteorological Organization (WMO) standard [28].

\section{DATA VALIDATION}

Three-year data set on hourly basis is used in this paper. This extensive time series has been validated manually and automatically (using computer-based techniques). Initially is validated automatically by taking advantage of the power and speed of computers and manually validate where more analysis is required. The validation process includes validation test of wind speed and direction data series in order to verify a normal operation band (wind speed between 0.0 and $25.0 \mathrm{~m} / \mathrm{s}$, and wind direction $\left.0^{\circ}-360^{\circ}\right)$. The data screening is used for the data series validation, filter by flag is used to remove questionable or erroneous, e.g. data like prolong calm time-periods. Results of validation process showed that the data series of wind speed and direction are inside the normal operation band. In addition, it is not necessary to apply any shifting to the time series of data based on the criteria concerning the maximum expected change of variable over time.

Missing data is a common problem in statistical analysis. Rates of less than $1 \%$ missing data are generally considered trivial, from 1 to $5 \%$ are manageable. However, from 5 to $15 \%$ requires sophistically methods to handle and more than $15 \%$ may severely impact any kind of interpretation [29]. Missing data is a source of uncertainty in wind energy resource assessment studies. Several publication recommend that missing data should not exceed $10 \%$ [10], and this paper assumed $10 \%$ value as maximum. The completeness of the collected data is assessed using the Data Recovery Rate (DDR), it is a measure of the amount of wind data successfully captured by the data logger and is expressed as a percentage of the data records available in a given period of time [10], [30]:

Data Recovery Rate $($ DDR $)=\frac{\text { Data records collected }}{\text { Data records available }} \times 100 \%$

where records collected is the difference between the data records possible and number of invalid records. The on-site measuring period shall be at least one year and the data recovery rate more than $90 \%$ in order to ensure the quality of the wind energy resource assessment [31]. The total data records possible during 3 successfully measured years is estimated at 26304 which results in a total recovery data of $97.23 \%$, and calculated yearly DDR of wind speed is $99.4 \%, 95.6 \%$ and $96.7 \%$ on 2008,2009 and 2010 respectively. Results of data recovery rate of wind direction during are lower than wind speed during the recording period: $98.7 \%, 95.0 \%$ and $96.2 \%$.

In this paper, a variation of the expectation maximization (EM) named regularized EM (RegEM) algorithm is used to replace any missing data and therefore complete the data set. MATLAB ${ }^{\mathrm{TM}}$ implementation of regularization methods is adapted to fit the framework of the EM algorithm, this is the EM Regularization Tools (RegEM) [32].

Results of data imputation and the main statistical index are shown in Table II. The statistical measure, Root Mean Square Error (RMSE) is used to indicate how closely the predicted values match the measured values. Results show RMSE below $0.5 \%$ for all times-series considered.

TABLE II. RESULTS OF WIND SPEED AND DIRECTION DATA IMPUTATION

\begin{tabular}{c|l|c|c|c}
\hline \hline Wind & \multicolumn{1}{|c|}{ Year } & 2008 & 2009 & 2010 \\
\hline \multirow{5}{*}{ Speed } & Iteration Number & 3 & 8 & 6 \\
& RMSE $(\%)$ & 0.365 & 0.325 & 0.421 \\
& MSE in Estimated Data $(\mathrm{m} / \mathrm{s})$ & 2.085 & 1.139 & 1.728 \\
\hline \multirow{3}{*}{ Direction } & Iteration Number & 14 & 6 & 12 \\
& RMSE $(\%)$ & 0.395 & 0.453 & 0.482 \\
& MSE in Estimated Data $\left({ }^{\circ}\right)$ & 7.624 & 7.415 & 8.676 \\
\hline
\end{tabular}

RMSE: Root Mean Square Error, MSE: Maximum Standard Error after using the EM algorithm.

\section{DATA PROCESSING}

\section{A. Temperature, Pressure and Air Density}

Fig. 2and Fig. 3 show monthly and averaged values of temperature and atmospheric pressure for the site, as assessed during the observation time. The temperature average registered is $27.55^{\circ} \mathrm{C}$ with the minimum diary is $14^{\circ} \mathrm{C}$, which is registered in May and maximum diary of $39^{\circ} \mathrm{C}$ during August. The maximum and minimum monthly mean temperatures are $32.6^{\circ} \mathrm{C}$ in September and $22^{\circ} \mathrm{C}$ in August.
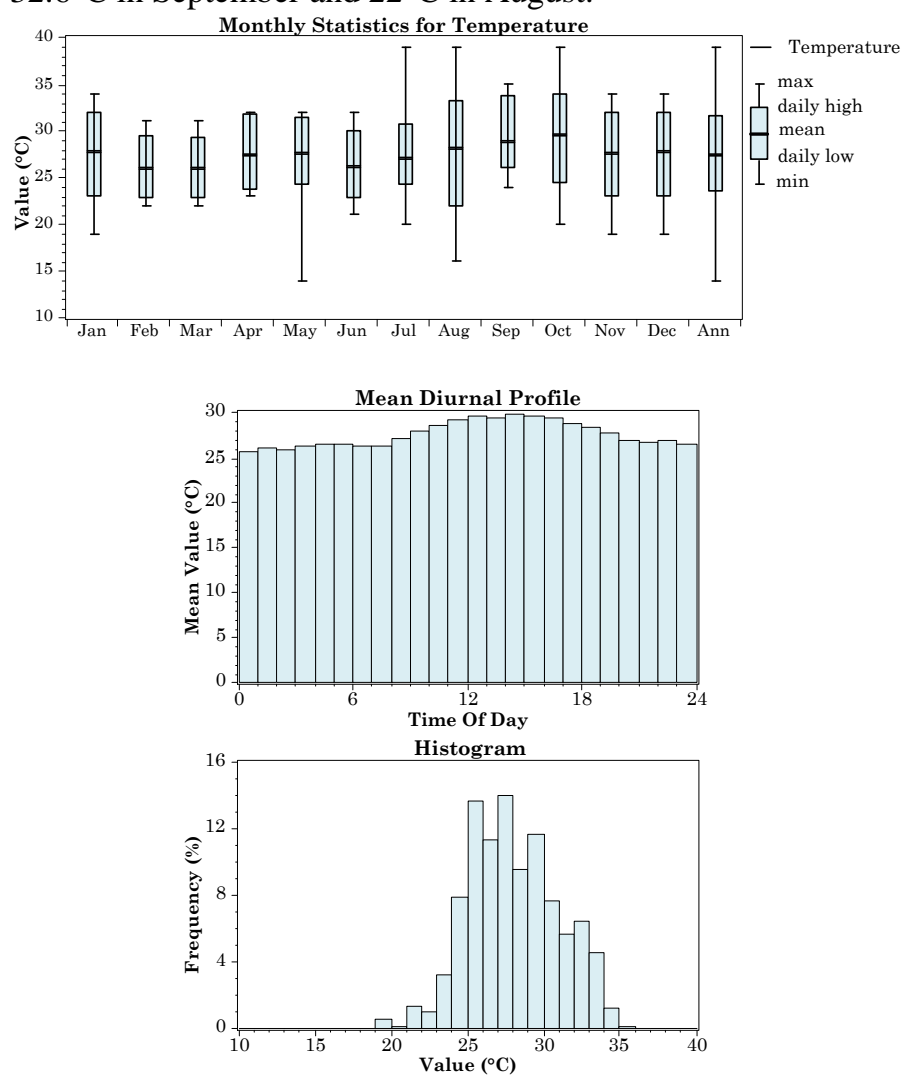

Fig. 2. Monthly and daily statistics of temperature.

The average atmospheric pressure varies between 1008.42 and 1013.51 mbar with yearly mean value of 1011.18 mbar. The maximum daily value is 1019 mbar which is registered in January and minimum daily is 1001.00 mbar during June and July. Mean diurnal profile shows small changes in atmospheric pressure and largest values are expected between 11:00 and 12:00 hours (1012.3 mbar).

The site-specific air density is calculated based on on-site 
measurement of air temperature and atmospheric pressure, the mean values during the observation period is $1.175 \mathrm{~kg} / \mathrm{m}^{3}$. The maximum and minimum monthly average air densities are $1.230 \mathrm{~kg} / \mathrm{m}^{3}$ in May and $1.124 \mathrm{~kg} / \mathrm{m}^{3}$ in August, respectively.

The normal environmental conditions are defined by IEC 61400 and it considers air density of $1.225 \mathrm{~kg} / \mathrm{m}^{3}$ at sea-level at $15^{\circ} \mathrm{C}$ to be normal [33], [34]. Average air density values at the observed point are below this standard value during the year, this means that the air density of the site would negatively affect the performance of a wind turbine most of the time. The energy in the wind will be reduced proportionally to the density of air and larger wind turbines are required for the same rated power compared with the conditions specified in the standard.

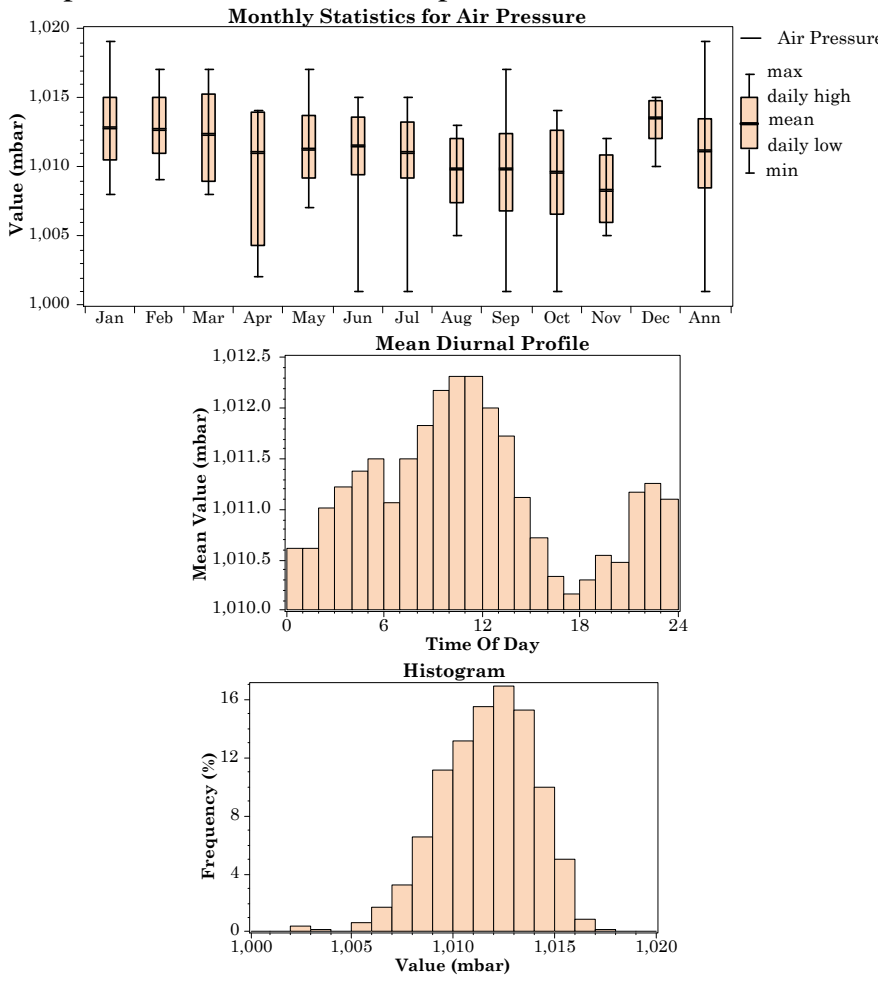

Fig. 3. Monthly and daily statistics of atmospheric pressure.

\section{B. Wind Speed}

The change in wind speed with height above ground, wind shear, can be approximated using Prandtl logarithmic law (logarithmic law or log law). This law assumes that the wind speed varies logarithmically with the height above ground [35] and uses the surface roughness (sometimes called surface roughness length or just roughness length) to characterize the wind shear. In this paper, the logarithmic law is used to approximate the wind shear of wind speed data set to height of $50 \mathrm{~m}$ and roughness length of $0.0024 \mathrm{~m}$ or Roughness Class $(R C)$ of 0.5 is assumed. Those values are representatives of open terrain with a smooth surface, such as concrete runways in airports, mowed grass.

A preliminary description of the wind speed at $50 \mathrm{~m}$ of the site for the observation period is created using boxplot, as shown on Fig. 4 where of five statistical measures: mean, average daily high and average daily low, maximum and minimum values. The monthly mean wind speed varies between 4.92 and $11.78 \mathrm{~m} / \mathrm{s}$. The maximum value of the mean wind speed occurs in June whilst the minimum value occurred in November and the average speed for the yearly mean is 8.29 $\mathrm{m} / \mathrm{s}$.

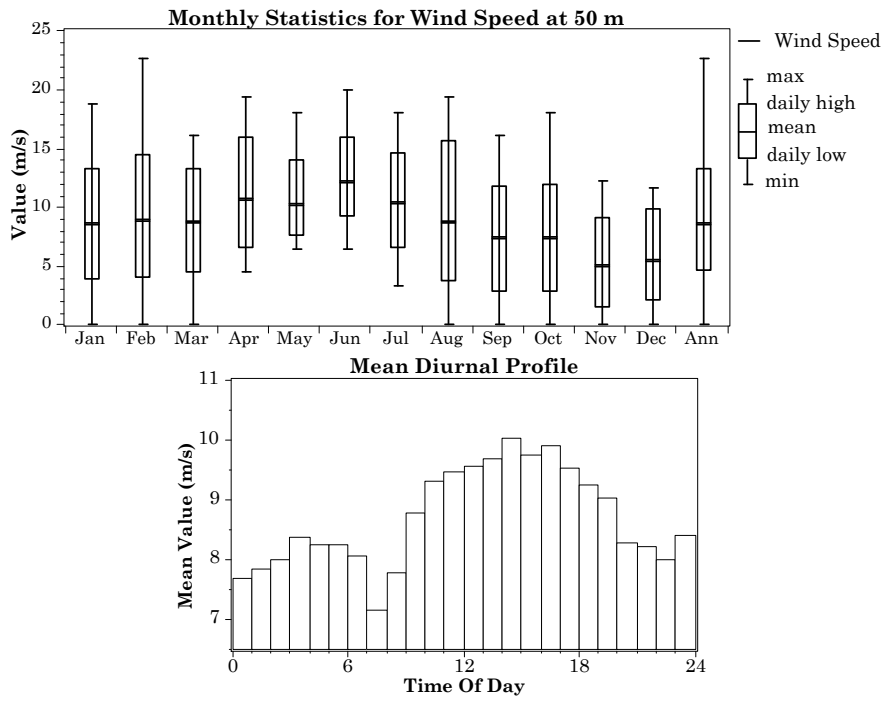

Fig. 4. Monthly statistics and daily profile for wind speed at $50 \mathrm{~m}$ height above ground.

The wind speed operating range of most horizontal axis wind turbines is defined between cut-in and cut-out wind speeds of about $4 \mathrm{~m} / \mathrm{s}$ and $25 \mathrm{~m} / \mathrm{s}$ respectively. It can be noted that the monthly average speeds is over the cut-in during whole year. The average daily high wind speed is $16.25 \mathrm{~m} / \mathrm{s}$ and occurs in June. The maximum hourly wind speed registration is 22.49 $\mathrm{m} / \mathrm{s}$ in June and this value is below the cut-out speed of most wind turbines. The wind speeds can be classed as calm $(<1.0$ $\mathrm{m} / \mathrm{s}$, below the cut-in wind speed for sensor) at least one hour during every nine months as can be seen in Fig. 4.

The diurnal wind speed profile is shown in Fig. 5, the mean daily wind speed profile over the observation period varies between $6.72 \mathrm{~m} / \mathrm{s}$ and $10.20 \mathrm{~m} / \mathrm{s}$ at 01:00 and 15:00 hours. The diurnal wind speed is $8.29 \mathrm{~m} / \mathrm{s}$ but the hourly profile recorded in June is the highest as $11.74 \mathrm{~m} / \mathrm{s}$.

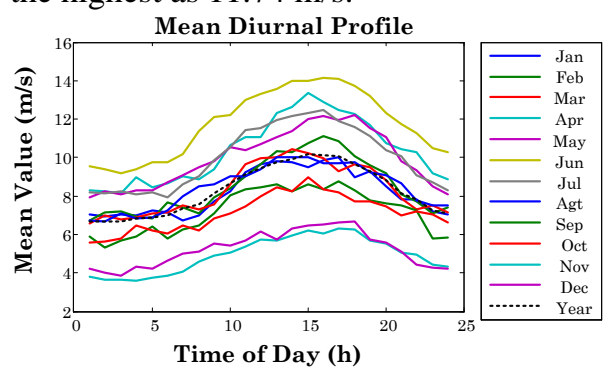

Fig. 5. Diurnal Wind Speed Profile.

There are several ways to study a one-dimensional data set. In this study, the statistical boxplot technique described by Wilks [36] is applied to establish the seasonal and inter-annual variabilities of wind speeds in recorded time series.

In Fig. 6(a)-6(e) the boxplots for the yearly groups are traced. The boxplots for the historical average wind speeds for each season of the year suggest the presence of some apparently atypical values (outliers, represented by the symbol +), especially in summer, Fig. 6(b), for the year 2 and 3. In Fig. 6(a)-6(b), it can observed that summer (June, July, and August -JJA) and autumn (September, October, and November -SON) produce the highest wind speed values for the yearly groups. 
Year 2 presents a higher median in summer with $9.845 \mathrm{~m} / \mathrm{s}$, Fig. 6(b), while in other seasons this value ranges between 5.345 and $9.494 \mathrm{~m} / \mathrm{s}$. According to the boxplots values presented in Fig. 6(a) and 6(b), year 1 and 3 have less variability in wind speed for each seasonal transition. The variability of the average annual wind speeds of the groups for the period 2008-2010 is presented in the boxplot of Fig. 6(e).

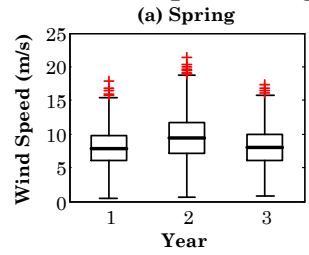

(c) Autumn

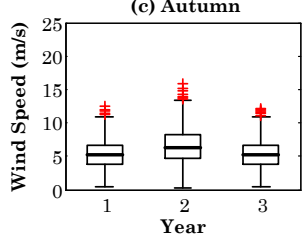

(b) Summer

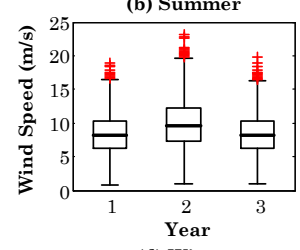

(d) Winter
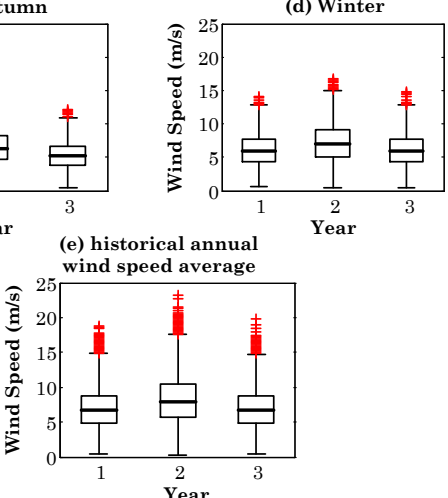

Fig. 6. Boxplot showing the variability of the seasonal average wind speed of the groups: (a) Spring, (b) Summer, (c) Autumn, (d) Winter, and (e) the historical annual wind speed average.

Two special time-periods are identified in the specific case of Venezuela: (a) rainy season from May to mid-November and (b) dry season from December to April. Rainy season presents higher wind speed compared with dry season.

The nonparametric Mann-Kendall test has been suggested by the WMO to assess the data trends in time series of environmental variables [37]. This test consists of comparing each value of the time series with the other values remaining in the sequential order. The trend analysis tests with the MannKendall method are summarized in Table III.

TABLE III. RESULTS OF THE MANN-KENDALL TESTS OF THE YEARS FOR SEASONAL AND INTER-ANNUAL VARIABILITIES.

\begin{tabular}{|c|c|c|c|c|c|c|}
\hline Year & Variable & Summer & "Spring & Autumn & "Winter & Year \\
\hline \multirow[b]{2}{*}{1} & \multirow{2}{*}{$\begin{array}{l}\text { Average }(\mathrm{m} / \mathrm{s}) \\
\text { Mann-Kendall } \\
\text { test }(\mathrm{Z})\end{array}$} & 8.319 & 7.986 & 5.345 & 6.111 & 6.940 \\
\hline & & -15.509 & 7.178 & -19.613 & 18.753 & -33.175 \\
\hline \multirow[b]{2}{*}{2} & \multirow{2}{*}{$\begin{array}{l}\text { Average }(\mathrm{m} / \mathrm{s}) \\
\text { Mann-Kendall } \\
\text { test }(\mathrm{Z})\end{array}$} & 9.845 & 9.494 & 6.521 & 7.191 & 8.263 \\
\hline & & -14.597 & 7.393 & -19.864 & 16.895 & -32.713 \\
\hline \multirow[b]{2}{*}{3} & \multirow{2}{*}{$\begin{array}{l}\text { Average }(\mathrm{m} / \mathrm{s}) \\
\text { Mann-Kendall } \\
\text { test }(\mathrm{Z})\end{array}$} & 8.310 & 8.012 & 5.293 & 6.120 & 6.934 \\
\hline & & -15.106 & 6.823 & -19.810 & 17.651 & -33.342 \\
\hline
\end{tabular}

It can be observed that the average annual wind speeds for years 1, 2, and 3 have a negative trend. In autumn, the decrease in speeds is more pronounced in Year 2 and 3, with significance levels of $p<0.05$. This trend is highest in Year 3 , with a value of -19.810 , representing an impact of climate variability and on wind resources. In some days of Year 2, wind intensity is greater than $6.521 \mathrm{~m} / \mathrm{s}$. The highest values in the Mann-Kendall trend test are found for autumn and winter in all years.

\section{Probability density functions}

The determination of wind speed distributions is carried out considering several probability density functions. Fig. 7 shows the frequency (\%) distribution of actual data and the best-fit Weibull probability distribution function considering several methods, and also the estimated parameters derived from the three-year observed data.

The top point of the curve is the most frequent wind speed as depicted in Fig. 9. The peak probability value is $5.67 \%$ with a mean wind speed of $7.81 \mathrm{~m} / \mathrm{s}$ and it corresponds with actual data. The results of the maximum likelihood algorithm to fit a Weibull distribution to a measured wind speed distribution shows that the dimensionless shape parameter $k$ is 2.59 while the scale parameter $c$ is $9.36 \mathrm{~m} / \mathrm{s}$ for the analysed site during the observation time period $\left(R^{2}=0.99091\right)$. This value for $k$ indicates that variation of hourly mean wind speed about the annual mean is small. The shape and scale parameters of the Weibull function are calculated for each month.

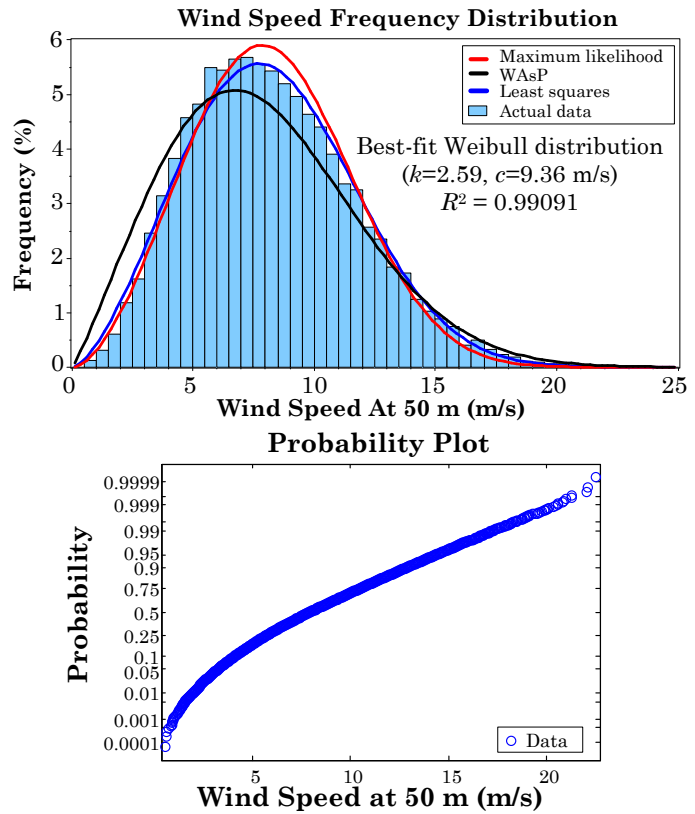

Fig. 7. Wind speed frequency distribution and best-fit Weibull distribution in the site assessed.

TABLE IV. MAIN STATISTICS AND PARAMETERS OF BEST-FIT WEIBULL DISTRIBUTION FUNCTION (ALL DIRECTIONS).

\begin{tabular}{cc|c|c|c}
\hline \hline & $\begin{array}{c}\text { Weibull } \\
k\end{array}$ & $\begin{array}{c}\text { Weibull } \\
c(\mathrm{~m} / \mathrm{s})\end{array}$ & $\begin{array}{c}\text { Mean } \\
\text { Speed }(\mathrm{m} / \mathrm{s})\end{array}$ & $\begin{array}{c}\text { Standard } \\
\text { Deviation } \\
(\mathrm{m} / \mathrm{s})\end{array}$ \\
\hline Jan & 3.078 & 9.154 & 8.208 & 2.856 \\
Feb & 2.694 & 9.509 & 8.528 & 3.468 \\
Mar & 3.341 & 9.285 & 8.325 & 2.708 \\
Apr & 4.223 & 11.453 & 10.272 & 2.797 \\
May & 5.550 & 10.975 & 9.842 & 1.944 \\
Jun & 6.243 & 12.888 & 11.555 & 1.968 \\
Jul & 4.144 & 11.097 & 9.949 & 2.864 \\
Aug & 2.228 & 9.371 & 8.401 & 4.091 \\
Sep & 2.175 & 7.972 & 7.148 & 3.533 \\
Oct & 2.558 & 7.956 & 7.137 & 2.926 \\
Nov & 2.668 & 5.362 & 4.809 & 2.119 \\
Dec & 3.296 & 5.840 & 5.236 & 1.686 \\
\hline
\end{tabular}

Table IV shows monthly Weibull parameters, mean speed and the standard deviations are summarized. As seen from this table, the Weibull shape parameter $k$ varies between 2.17 and 6.24 while the scale parameter $c$ varies between 5.36 and 12.88 
$\mathrm{m} / \mathrm{s}$. The lowest $c$ value is found in November and the highest value in June. The wind at the site is therefore expected to be highly uniform during June. The lowest standard deviation is $1.68 \mathrm{~m} / \mathrm{s}$ and occurs in December.

Fig. 8 shows the cumulative probability distribution (CDF) of wind speed at the assessed site during the observation time period and also the best-fit of Weibull are depicter, Normal distribution is complementary. The Kolmogorov-Smirnov test (K-S test) [38] has been used to evaluate goodness of fit. Results of K-S test show Weibull distribution has higher goodness of fit at $5 \%$ significance level $(K S=0.0407)$ than Normal distribution $(K S=0.0204)$.

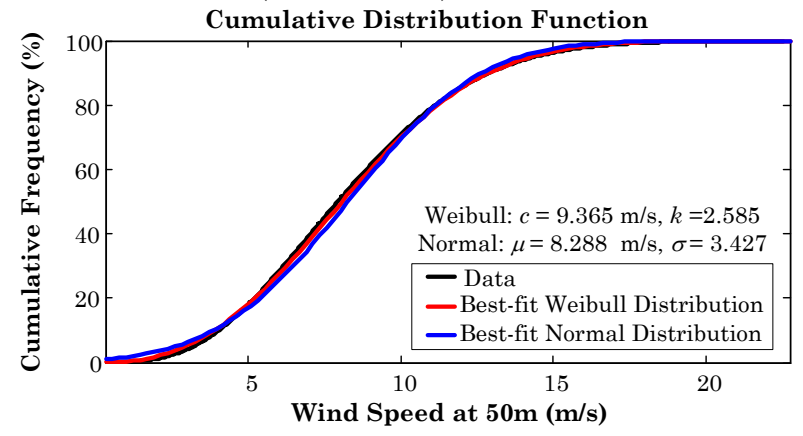

Fig. 8.Cumulative probability distribution of Wind Speed at the assessed site.

The time that a turbine can generate power is estimated using the Weibull CDF. For a wind turbine with a cut-in speed of 4 $\mathrm{m} / \mathrm{s}$ and a cut-out speed of $25 \mathrm{~m} / \mathrm{s}$ installed at this site, wind resource will generate power for 20.10 hours a day (probability $=0.8378$ ). It is expected the wind speed is within the necessary operating region during 7339 hours per year and the probability wind speed exceed $35 \mathrm{~m} / \mathrm{s}$ is negligible (probability $=1.116 \times 10^{-}$ $21)$.

\section{Wind Direction}

The direction of the wind is an important factor when determining the layout of a wind farm or any wind energy conversion system.

Fig. 9 shows the relative frequency (\%) of wind directions and mean wind speed. This wind frequency rose representation is used to show the frequency that wind direction falls within each direction sector. In this case, the Weibull histograms are determined for 16 sectors at $50 \mathrm{~m}$ height. According to Fig. 9(a), the frequency at which the wind blows from the East (at a wind speed above the calm threshold) is about $97 \%$ and the estimated calm frequency is $3 \%$. This means the wind speed is equal to $0.0 \mathrm{~m} / \mathrm{s}$ in more than 263.40 hours per year. The prevailing wind direction is the East-West direction.

The mean speed wind rose plots the average wind speed value for a particular wind direction, as shown in Fig. 9(b). According to this figure, the wind rose indicates that winds from the East direction tend to be the strongest, with an average wind speed of over $9.67 \mathrm{~m} / \mathrm{s}$ and winds from the West direction tend to be the lightest, averaging less than $5.76 \mathrm{~m} / \mathrm{s}$.

Table $\mathrm{V}$ shows the Weibull parameters for the mean wind speed rose. As seen in this table, the Weibull shape parameter $k$ varies between 1.32 and 4.42 while the scale parameter $c$ varies between 5.75 and $10.33 \mathrm{~m} / \mathrm{s}$. The lowest $c$ value corresponds to wind blowing from North, whereas the highest value is for wind blowing from East. Wind rose analysis shows that winds in Los Taques are very unidirectional; more than $74.62 \%$ of the year the wind comes from East $\left(62.5^{\circ}-112.5^{\circ}\right)$, this is likely a result of the thermal effects seen in this region. In this type of site, the wind turbines tend to be arranged in tightly packed rows, perpendicular to the wind, with large spaces downwind to minimize wake effects.
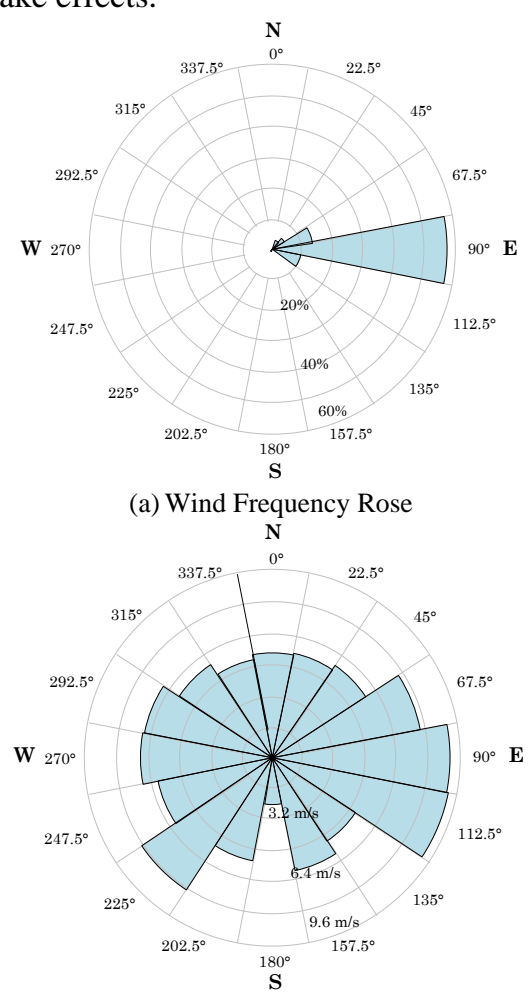

(b) Mean of Wind Speed

Fig. 9.Frequency (\%) and mean speed of wind directions.

TABLE V. PROBABILITY DISTRIBUTION FUNCTION OF MEAN WIND SPEED PER SECTOR.

\begin{tabular}{ccccc}
\hline \hline Sector & $\begin{array}{c}\text { Weibull } \\
k\end{array}$ & $\begin{array}{c}\text { Weibull } \\
c(\mathrm{~m} / \mathrm{s})\end{array}$ & $\begin{array}{c}\text { Mean } \\
\text { Speed }(\mathrm{m} / \mathrm{s})\end{array}$ & $\begin{array}{c}\text { Mean } \\
(\mathrm{m} / \mathrm{s})\end{array}$ \\
\hline $348.75^{\circ}-11.25^{\circ}$ & 2.407 & 6.1091 & 4.5490 & 4.9156 \\
$11.25^{\circ}-33.75^{\circ}$ & 2.376 & 6.2046 & 4.6053 & 5.5240 \\
$33.75^{\circ}-56.25^{\circ}$ & 2.189 & 6.5291 & 4.8476 & 5.5240 \\
$56.25^{\circ}-78.75^{\circ}$ & 2.544 & 8.7367 & 6.4976 & 7.3614 \\
$78.75^{\circ}-101.25^{\circ}$ & 2.964 & 10.2607 & 7.6657 & 8.5903 \\
$101.25^{\circ}-123.75^{\circ}$ & 3.033 & 10.3354 & 7.7265 & 9.8192 \\
$123.75^{\circ}-146.25^{\circ}$ & 4.415 & 8.1459 & 4.3439 & 4.9156 \\
$146.25^{\circ}-168.25^{\circ}$ & 2.054 & 6.6779 & 4.9300 & 6.1325 \\
$168.75^{\circ}-191.25^{\circ}$ & 1.319 & 2.6703 & 2.0550 & 2.4578 \\
$191.25^{\circ}-213.25^{\circ}$ & 1.963 & 6.1468 & 4.5325 & 4.9156 \\
$213.75^{\circ}-236.25^{\circ}$ & 2.67 & 8.2719 & 6.7880 & 8.5903 \\
$236.25^{\circ}-258.75^{\circ}$ & 2.583 & 6.7588 & 5.0411 & 6.1325 \\
$258.75^{\circ}-281.25^{\circ}$ & 2.701 & 7.6355 & 5.7060 & 6.1325 \\
$281.25^{\circ}-303.75^{\circ}$ & 2.265 & 7.6176 & 5.6421 & 6.1325 \\
$303.75^{\circ}-326.75^{\circ}$ & 2.211 & 6.3665 & 4.8061 & 5.5240 \\
$326.25^{\circ}-348.75^{\circ}$ & 2.887 & 5.7597 & 4.3063 & 4.9156 \\
\hline
\end{tabular}

\section{E. Wind Power Density (WPD)}

A useful way to assessment the wind resource available at Los Taques is the Wind Power Density (WPD) because provides an idea about the mean energy content of the wind resource. Fig. 10 shows monthly variations of the mean WPD which is calculated using the wind speed data set during the observation period. Fig. 10 shows the mean WPDs are highly variable during the observation period. Large monthly and daily changes are evident, the minimum daily value is different to 0.0 
$\mathrm{W} / \mathrm{m}^{2}$ from April to July and maximum daily, $6740.11 \mathrm{~W} / \mathrm{m}^{2}$ is reached in February. The annual average WPD was 582.08 $\mathrm{W} / \mathrm{m}^{2}$ over the whole period. The monthly mean WPD varies between 141.02 in November to $1169.33 \mathrm{~W} / \mathrm{m}^{2}$ in June.
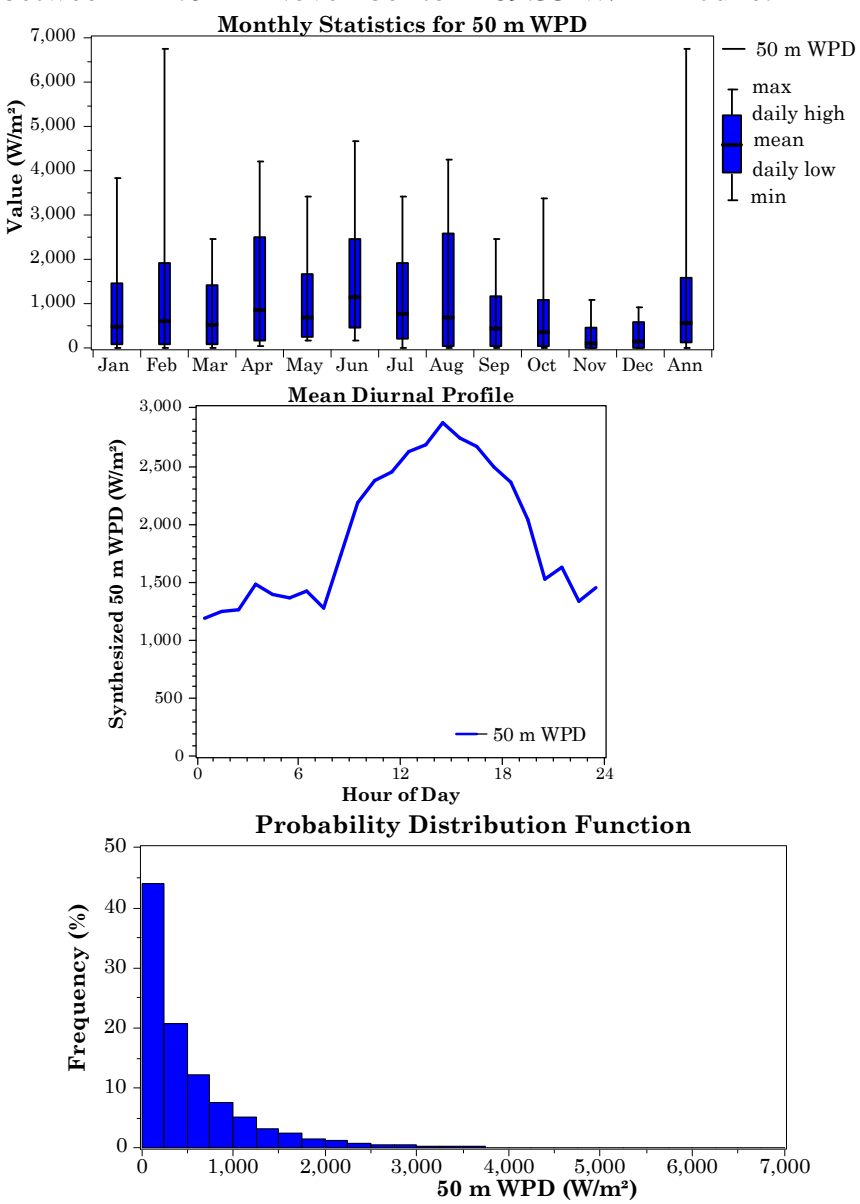

Fig. 10. Monthly variation of the mean power density.

The wind power class is a number indicating the mean energy content of the wind resource. Wind power classes are based on the mean wind power density at 50 meters above ground, according to Table VI.

TABLE VI. CLASSES OF WIND POWER DENSITY AT $50 \mathrm{M}$ [39], [40].

\begin{tabular}{cccc}
\hline $\begin{array}{c}\text { Wind } \\
\text { Power } \\
\text { Class }\end{array}$ & Description & $\begin{array}{c}\text { Wind Power } \\
\text { Density }\left(W / \mathrm{m}^{2}\right)\end{array}$ & $\begin{array}{c}\text { Wind Speed } \\
(\mathrm{m} / \mathrm{s})\end{array}$ \\
\hline 1 & Poor & $<200$ & $<5.6$ \\
2 & Marginal & $200-300$ & $5.6 / 6.4$ \\
3 & Fair & $300-400$ & $6.4 / 7.0$ \\
4 & Good & $400-500$ & $7.0 / 7.5$ \\
5 & Excellent & $500-600$ & $7.5 / 8.0$ \\
6 & Outstanding & $600-800$ & $8.0 / 8.8$ \\
7 & Superb & $>800$ & $>8.8$ \\
\hline
\end{tabular}

According to the wind power classes shown in Table VI, the site assessed exhibits an excellent mean power density during the year $\left(>500 \mathrm{~W} / \mathrm{m}^{2}\right)$. It must be noticed the monthly values range between poor $\left(<200 \mathrm{~W} / \mathrm{m}^{2}\right)$ and superb $\left(>800 \mathrm{~W} / \mathrm{m}^{2}\right)$.

Fig. 11 shows empirical CDF of WPD and an as example the best-fit CDF using a negative binomial distribution is depicted. It is difficult to give a physical interpretation in this case to the individual parameters, for this reason the empirical CDF is used for results interpretations. It can be observed the power density is superb $\left(>800 \mathrm{~W} / \mathrm{m}^{2}\right)$ about $21.56 \%$ of the total time, 5.17 hours per day, and the WPD is considered poor $\left(<200 \mathrm{~W} / \mathrm{m}^{2}\right)$ during 9.17 hour per day $(38.21 \%)$.

The cumulative distribution of wind power density, presented in Fig 11, shows that less than $50 \%$ of the time, the wind power density is equal to or less than $309 \mathrm{~W} / \mathrm{m}^{2}$, but values above $750 \mathrm{~W} / \mathrm{m}^{2}$ are reached less than $25.05 \%$ of the time.

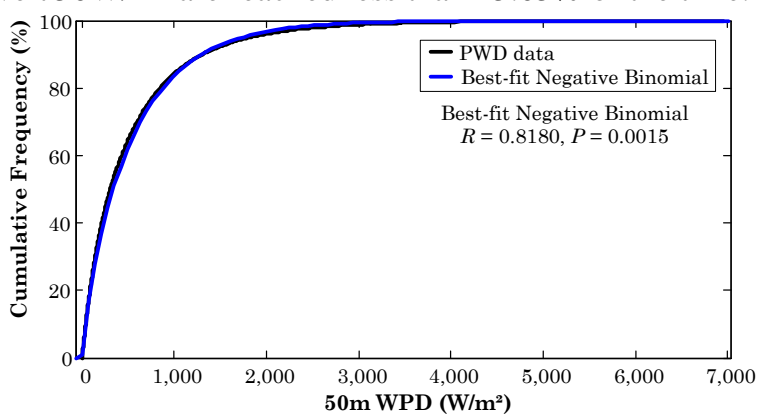

Fig. 11. Wind power density cumulative probability distributions in the site.

\section{F. Wind Power of Selected Turbines and Energy Output}

Estimation of energy output from a wind turbine to be installed at a selected site will determine if there is sufficient energy available to make the site commercially viable. The annual energy output from a wind turbine depends on the electrical power output from the wind turbine for the wind speed distribution experienced.

In order to select a wind turbine for a specific location, it is necessary to match it with the wind characteristics of the site (it should yield an optimum energy) in order to obtain a high capacity factor $\left(C_{F}\right)$ to meet the electrical energy demand.

In this paper, for general evaluative purposes, eight different wind turbines have been selected: $(A)$ Gamesa G-52, (B) Made AE-61, $(C)$ Vestas V-80, (D) IMPSA IWP- 83, $(E)$ Nordex N90LS, $(F)$ Vestas V90, $(G)$ REpower 5M and $(H)$ REpower 6M. The main properties of these wind turbines are given in Table VII. The power curves for the four turbines with different rated powers are shown in Fig. 12.

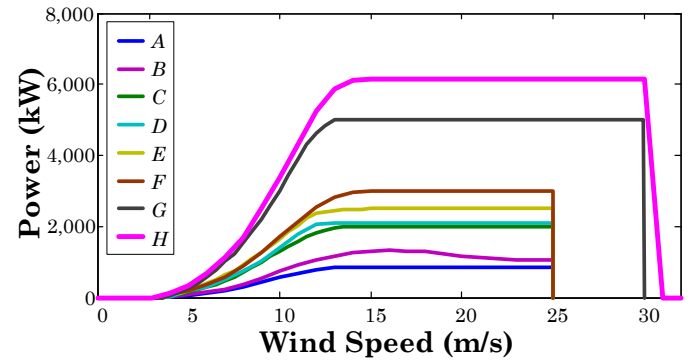

Fig. 12. Power curves comparison for selected wind turbines. TABLE VII. MAIN CHARACTERISTICS OF FIVE DIFFERENT COMMERCIAL WIND TURBINES.

\begin{tabular}{c|c|c|c|c|c}
\hline \hline Turbine & $\begin{array}{c}\text { Hub } \\
\text { height } \\
(\mathrm{m})\end{array}$ & $\begin{array}{c}\text { Rated } \\
\text { power } P_{r} \\
(\mathrm{~kW})\end{array}$ & $\begin{array}{c}\text { Swept } \\
\text { Area } \\
\left(\mathrm{m}^{2}\right)\end{array}$ & $\begin{array}{c}\text { Power } \\
\text { Regulation }\end{array}$ & $\begin{array}{c}\text { Generator } \\
\text { type }\end{array}$ \\
\hline$A$ & 65 & 850 & 2124 & PAC & DFAG \\
$B$ & 65 & 1320 & 2922 & SR & AG \\
$C$ & 60 & 2000 & 5027 & PAC & DFAG \\
$D$ & 100 & 2100 & 5410 & PAC & DDPM \\
$E$ & 70 & 2500 & 7854 & PAC & DFAG \\
$F$ & 65 & 3000 & 6362 & PAC & DFAG \\
$G$ & 100 & 5000 & 49875 & PAC & DFAG \\
$H$ & 100 & 6100 & 49875 & PAC & DFAG \\
\hline
\end{tabular}

Power Regulation: PAC: Pitch Angle Control, SR: Stall Regulated

Generator Type: DFAG: Double Asynchronous generator, AG: Asynchronous Generator, DDPM: Direct Drive Permanent Magnet 
Table VIII shows the wind turbine output calculation for selected wind turbines using the wind regimen available in Los Taques.

\begin{tabular}{|c|c|c|c|c|c|}
\hline Turbine & $\begin{array}{l}\text { Time at } \\
\text { zero } \\
\text { output } \\
(\%)\end{array}$ & $\begin{array}{l}\text { Time } \\
\text { at } \\
\text { rated } \\
\text { output } \\
(\%)\end{array}$ & $\begin{array}{l}\text { Mean } \\
\text { Net } \\
\text { power } \\
\text { output } \\
(\mathrm{kW})\end{array}$ & $\begin{array}{c}\text { Mean Net } \\
\text { Energy } \\
\text { Output } E_{\text {out }} \\
\text { (kW/year) }\end{array}$ & $\begin{array}{c}\text { Net } \\
\text { Capacity } \\
\text { Factor } \\
C_{F}(\%)\end{array}$ \\
\hline$A$ & 10.01 & 12.17 & 362.40 & $3,174,546$ & 42.6 \\
\hline$B$ & 10.14 & 0.51 & 478.30 & $4,190,291$ & 36.2 \\
\hline$C$ & 11.57 & 13.22 & 828.70 & $7,259,580$ & 41.4 \\
\hline$D$ & 11.22 & 23.44 & 910.80 & $7,978,507$ & 43.4 \\
\hline E & 11.40 & 14.43 & $1,073.20$ & $9,401,554$ & 42.9 \\
\hline$F$ & 9.93 & 12.29 & $1,197.00$ & $10,485,328$ & 39.9 \\
\hline G & 12.58 & 23.42 & $2,057.00$ & $18,019,224$ & 41.1 \\
\hline$H$ & 4.23 & 21.02 & $2,770.10$ & $24,265,872$ & 45.0 \\
\hline
\end{tabular}

The overall loss factor has been considered equal to $17.70 \%$. An outstanding annual average speed $(6.94 \mathrm{~m} / \mathrm{s})$ is available in Los Taques. However, $3 \%$ of calm provides a relatively long period for which the wind turbines are out of service because the wind speed is below their cut-in speed.

The Turbine $C$ is the wind turbine with the highest percentage of time at zero output; this is particularly true from September to December: $13.61 \%, 13.31 \%, 30.28 \%$ and $18.15 \%$ respectively. November is the worst month in terms of zero output for almost all selected wind turbines: $C: 30.28 \%, A$ : $21.94 \%, D: 21.94 \%$ and $E: 21.94 \%$. In fact, November and December are the worst months in terms of output power production. The poor performance during these months is characterized by the fact that during them none of the selected turbines operate at rated power, as presented in Fig. 13.

The net mean energy output for the selected wind turbines is in the range of $3.17 \mathrm{GWh} /$ year to $24.65 \mathrm{GWh}$ /year. The highest net mean energy output and capacity factor is obtained with a turbine $H(6100 \mathrm{~kW})$. Sometimes it is advantageous to use a larger generator with the same rotor diameter. This would tend to reduce the capacity factor, but may afford a substantially larger annual production. This is the case in site under consideration because it is a very windy location.

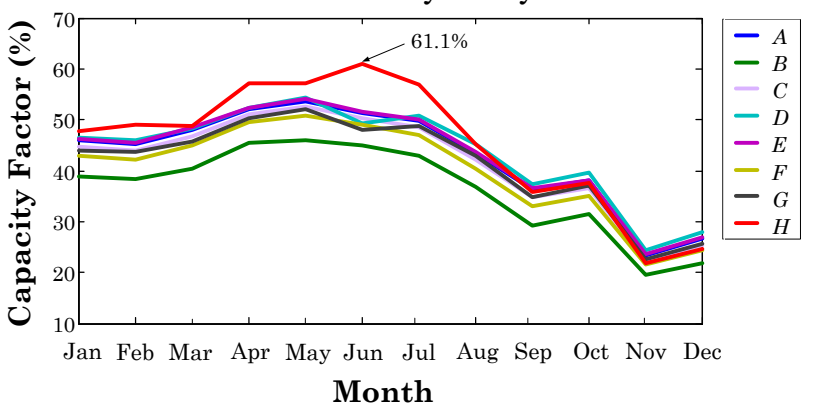

Fig. 13. Monthly Capacity Factor $(\%)$ of selected wind turbines.

A hypothetical wind farm of $100 \mathrm{MW}$ based on turbine $H$ can produce around $395.28 \mathrm{GWh} /$ year. This production is relatively high compared with the $316.22 \mathrm{GWh} /$ year that would be produced by a wind farm based on $B$ wind turbine. In this case, the evaluation indicates the best option is use wind turbine $H$ in the site under investigation.

\section{CONCLUSIONS}

The results obtained in this paper for Los Taques show that the wind energy potential is sufficient for its use as a primary energy to produce electricity commercially, this is an important contribution because defines the starting point for more deeper evaluations. Results of this preliminary assessment have demonstrated an outstanding wind class in terms of annual average wind speed at $50 \mathrm{~m}$ in addition to annual wind density of excellent class. This quality of wind resource is suitable for electrical power production through the installation of wind farms. Wind rose analysis shows the winds in Los Taques are very unidirectional and blow strongly and frequently from the east. Although four seasons are not available in Venezuela, two pseudo-seasons, consisting of September to January and February to August, can be used to characterize the wind energy resource. Nevertheless, the one wind farm in this location could not produce electricity whole year. The September to January period mostly consists of wind speeds below those considered as good winds. In contrast the February to August period mostly consists of wind speeds which qualify as excellent. An evaluation of several commercially available wind turbines has shown a good performance for a $6.0 \mathrm{MW}$ wind turbine. However, the power output for this wind turbine is relatively low; it is estimated to be $2.71 \mathrm{MW}$, which is equivalent to 24.65 GWh/year of exploitable wind energy. Energy production for valuations for a $100 \mathrm{MW}$ wind farm indicates the maximum production is obtained with a 6.0. MW wind turbine. The results obtained in this paper show that the wind energy potential in Los Taques is sufficient for use as the primary energy source for the commercial generation of electrical energy, a further evaluation of wind energy resource is recommended to provide a long term estimation of the wind regime.

\section{REFERENCES}

[1] F. González-Longatt, J. Serrano González, M. Burgos Payán, and J. M. Riquelme Santos, "Wind-resource atlas of Venezuela based on on-site anemometry observation," Renewable and Sustainable Energy Reviews, vol. 39, pp. 898-911, 11// 2014.

[2] S. Bautista, "A sustainable scenario for Venezuelan power generation sector in 2050 and its costs," Energy Policy, vol. 44, pp. 331-340, 5// 2012

[3] G. Massabie, Venezuela: A Petro-State Using Renewable Energies - A Contribution to the Global Debate about New Renewable Energies for Electricity Generation: VS Verlag für Sozialwissenschaften, 2008.

[4] F. Gonzalez-Longatt, "Systemic Impact Caused by the Integration of La Guajira Wind Farm," presented at the 39th Annual Conference of the IEEE Industrial Electronics Society (IECON 2013), Vienna, Austria, 2013.

[5] F. González-Longatt, J. Méndez, and R. Villasana, "Preliminary Evaluation of Wind Energy Utilization on Margarita Island, Venezuela," in Sixth International Workshop on large-Scale of Integration of Wind Power and Transmission Networks for Offshore Wind Farms, Delft, Netherlands, 2006.

[6] F. González-Longatt, J. Méndez, R. Villasana, and C. Peraza, "Wind Energy Resource Evaluation on Venezuela: Part I," presented at the Nordic Wind Power Conference NWPC 2006, Espoo, Finland, 2006.

[7] F. M. Gonzalez-Longatt, "Systemic impact caused by the integration of La Guajira wind farm," in Industrial Electronics Society, IECON 2013 39th Annual Conference of the IEEE, 2013, pp. 1893-1897.

[8] F. Gonzalez-Longatt, "Evaluation of Reactive Power Compensations for the Phase I of Paraguaná Wind based on System Voltages," presented at the 39th Annual Conference of the IEEE Industrial Electronics Society (IECON 2013), Vienna, Austria, 2013.

[9] M. Sathyajith, Wind Energy: Fundamentals, Resource Analysis and Economics: Springer-Verlag New York, Inc., 2006.

[10] B. H. Bailey, S. L. McDonald, D. W. Bernadett, M. J. Markus, and K. V. Elsholz, "Wind Resource Assessment Handbook: Fundamentals for conducting a successful monitoring program," NREL/SR-440-22223; 
ON: DE97000250; Other: ON: DE97000250; TRN: US200311\%\%76, 1997.

[11] T. Burton, D. Sharpe, N. Jenkins, and E. Bossanyi, Wind Energy Handbook: John Wiley \& Sons, 2001.

[12] P. Gardner, Garrad, A., Jamieson, P., Snodin, H., Nicholls, G., and Tindal, A. (2004). Wind Energy - The Facts - Technology (Volume 1). Available: http://www.ewea.org/fileadmin/ewea_documents/documents/publication s/WETF/Facts_Volume_1.pdf

[13] Know Your Wind. Available: http://www.windustry.org/basics/04knowwind.htm

[14] D. Andre, Grove, J., Grossman, L., Moynihan, S.P., and Raker, J. (2005). Wind: An Oregon Guidebook. Available: http://www.energytrust.org/RR/wind/community/oregon_wind_guidebo ok.pdf

[15] L. Landberg and N. Mortensen, "A comparison of physical and statistical methods for estimating the wind resource at a site," in 5th British Wind Energy Association Conference, 1993, pp. 119-125.

[16] J. F. Manwell, Wind energy explained : theory, design and application. Chichester ;: Wiley, 2002.

[17] L. Landberg, L. Myllerup, O. Rathmann, E. L. Petersen, B. H. Jørgensen, J. Badger, et al., "Wind Resource Estimation-An Overview," Wind Energy, vol. 6, pp. 261-271, 2003.

[18] S. AL-Yahyai, Y. Charabi, A. Gastli, and S. Al-Alawi, "Assessment of wind energy potential locations in Oman using data from existing weather stations," Renewable \& Sustainable Energy Reviews, vol. 14, pp. 14281436, Jun 2010.

[19] I. Fyrippis, P. J. Axaopoulos, and G. Panayiotou, "Wind energy potential assessment in Naxos Island, Greece," Applied Energy, vol. 87, pp. 577586, Feb 102010.

[20] O. O. Ajayi, "Assessment of utilization of wind energy resources in Nigeria," Energy Policy, vol. 37, pp. 750-753, Feb 2009.

[21] G. Bekele and B. Palm, "Wind energy potential assessment at four typical locations in Ethiopia," Applied Energy, vol. 86, pp. 388-396, Mar 2009.

[22] A. Ucar and F. Balo, "Evaluation of wind energy potential and electricity generation at six locations in Turkey," Applied Energy, vol. 86, pp. 1864$1872,2009$.

[23] R. Köse, "An evaluation of wind energy potential as a power generation source in Kütahya, Turkey," Energy Conversion and Management, vol. 45, pp. 1631-1641, 2004

[24] AWEA, "Standard Procedures for Meteorological Measurements at a Potential Wind Turbine Site," in AWEA Standard 8.1-1986, ed. Alejandria, VA: American Wind Energy Association, 1996.

[25] AWEA, "Standard Performance Testing of Wind Energy Conversion Systems," in AWEA Standard 1.1-1988, ed. Alexandria, VA: American Wind Energy Association, 1998.

[26] M. Stevens and P. Smulders, "The estimation of the parameters of the Weibull wind speed distribution for wind energy utilization purposes," Wind Engineering, vol. 3, pp. 132-142, 1979.

[27] S. Emeis, Wind Energy Meteorology Atmospheric Physics for Wind Power Generation. Berlin Heidelberg: Springer-Verlag, 2013.

[28] WMO, "Guide to Meteorological Instruments and Methods of Observation," World Meteorological Organization, Geneva2008.

[29] B. Lotfi, M. Mourad, M. B. Najiba, and E. Mohamed, "Treatment methodology of erroneous and missing data in wind farm dataset," in Systems, Signals and Devices (SSD), 2011 8th International MultiConference on, 2011, pp. 1-6.

[30] K. Meah and A. H. M. S. Ula, "On-Site Wind Energy Measurement and Preliminary Transmission Assessment: Case Studies in Wyoming," in Region 5 Conference, 2008 IEEE, 2008, pp. 1-6.

[31] HydroChina. Group, "Compiling Methods for Feasibility Study Report of Wind Farm Projects," HydroChina Group WED- B01 E1, 2009.

[32] P. C. Hansen, "Regularization Tools Version 4.1 (for Matlab Version 7.3)," 7.3 ed, 1994.

[33] IEC, "Wind turbines - Part 12-1: Power performance measurements of electricity producing wind turbines," in IEC 61400-12-1 International Standard, ed: International Electrotechnical Commission, 2005.

[34] ISO, "Standard Atmosphere," in ISO International Standard 2533-1975, ed. Geneva, Switzerland: International Organization for Standardization, 1978, p. 112

[35] M. C. Brower, Wind Resource Assessment: A Practical Guide to Developing a Wind Project. Hoboken, New Jersey: John Wiley and Sons, 2012.

[36] D. S. Wilks, Statistical Methods in the Atmospheric Sciences, vol. 100 of International Geophysics Series, 3rd Edition ed. New York, NY, USA.
[37] V. D. P. R. d. Silva, P. V. D. Azevedo, R. S. Brito, and J. H. B. D. C. Campos, "Evaluating the urban climate of a typically tropical city of northeastern Brazil," Environmental Monitoring and Assessment, vol. 116, pp. 45-59, 2010.

[38] F. J. Massey, "The Kolmogorov-SmirnovTest for Goodness of Fit," Journal of the AmericanStatistical Association, vol. 46, pp. 68-78, 1951.

[39] R. L. Busby, Wind Power: The Industry Grows Up. Oklahoma, USA: PennWell Books, 2012.

[40] NREL. (2013). Wind Energy Resource Atlas of the United StatesWind Data Details. Available: http://rredc.nrel.gov/wind/pubs/atlas/ 